DOI https://doi.org/10.18551/rjoas.2016-11.13

\title{
THE EFFECT OF PERFORMANCE AGREEMENT, EMPLOYEE INVOLVEMENT, FACILITATION, ASSESSMENT AND FEEDBACK TOWARDS EMPLOYEE PERFORMANCE: A STUDY IN PT. SURYA PAMENANG, JAWA TIMUR PROVINCE, INDONESIA
}

\author{
Ansory Al Fadjar* \\ University of Kadiri, Indonesia \\ Salim Ubud, Sudiro Achmad, Khusniah Nur \\ University of Brawijaya, Indonesia \\ *E-mail: luqman.academia@gmail.com
}

\begin{abstract}
Facing ASEAN Economic Community to deal with foreign companies from various countries needs optimal resources so that local enterprises could increase the employee performance. This study aims to analyze the influence of performance agreement, facilitation, assessment, feedback, employee involvement towards employee performance. The inferential statistical analysis used was SEM (Structural Equation Modeling) by collecting data through a survey at PT. Surya Pamenang, Kediri, Jawa Timur Province, Indonesia as many as 150 respondents. The analysis proved that there is a significant positive influence in between the performance agreement, facilitation, assessment, feedback, employee involvement towards employee performance.
\end{abstract}

\section{KEY WORDS}

Performance agreement, facilitation, assessment, feedback, employee involvement, employee performance.

In regard to the free trade system, starting with the opening of Asean Economic Community (AEC, in Indonesian term, is called as Masyarakat Ekonomi Asean or MEA) in 2015 as well as several other free trade systems, Indonesian companies should be prepared to compete with foreign companies from various countries. This requires resources optimization in the enterprises to produce profit, one of which is by human resources. Human resources management which is in relation to superior and subordinate relationships can not be separated from employee involvement. Macey et al, (2009) say that more maximum result is an important step in the process of performance management, starting from the performance agreement for the performance management process.

\section{LITERATURE REVIEW}

A performance agreement is a psychological contract. Kahn (1990) argues that there are 3 psychological conditions to increase the employee involvement in the workplace such as psychological significance, psychological security, and psychological availability. In psychological significance, employees tend to choose the contracts that are considered beneficial for themselves, while psychological safety is the thought to get a guarantee of protection, they also believe that they have the resources to serve as a psychological availability. Employees tend to have implicit or explicit expectations about their organization / job (Rousseau, 1990). That hope can be the basis of the psychological contract which involves mutual obligations between the employee and the company. The fulfillment of psychological contract has been shown to be associated with on-duty performance and nonduty performance of the company to the employees (Turnley, et al, 2003).

Involvement facility focuses on the identification of the resources that needed by the employee (Gruman and Saks, 2011). These activities include work design, training, social 
support, and leadership. Buchner (2007) and Giles and Mossholder (1990) says that the design of an effective job is by enabling employees to provide advice in the course of employment. Wrzesniewski and Dutton (2001) explains one of the ways that the employees do to modify their job is to"change the number, scope, or type of the job tasks in the workplace". Training and social support, both should be an ongoing process and should not be limited by the quarterly or annual performance evaluation. As noted by Murphy and DeNisi (2008), performance management that is designed to motivate the employees to perform better is training. Another opinion is suggested by Schaufeli and Salanova (2007) that one of the keys to maintaining the employee involvement is by allowing them to continue developing their careers. Leaders have an important role in the provision of duty and support for the employees to improve the employee involvement (Schaufeli and Salanova, 2008).

Involvement assessment includes trust and equality or fairness during the performance assessment, involvement assessment, and feedback. The trustworthy and fair performance assessment will provide security for the employees to perform involvement in work, enabling them to increase productivity and produce positive results (Pulakos, et al, 2008). According to Macey and Schneider (2008), trust has a central role in the process of employee involvement, because they believe that their investment of energy, time and personal resources is being respected. London (2003) explains involvement feedback as; it can provide functional information to help employees learn the duties of their new jobs, to become familiar with the norms of the work environment, to identify the opportunities to develop skills and abilities or to maintain productivity. A positive feedback allowed the employees to increase their involvement and performance further (Schaufeli and Salanova, 2007).

Employee involvement has the attention of several types of research in recent years, it is considered as a key to improving the performance of a company. Schaufeli and Salanova (2007) says that involvement or engagement is an "essence" for the company organization today, in regard to many challenges that must be faced by the company at this time. Macey, et al (2009) states that a company organization can be ahead of the competition through this employee involvement.

Leiter and Bakker (2010) said that work involvement has a deep implication for the employee performance. The energy and focus which are inherent in the work involvement allow them to bring their full potential at work. The focus of this energy is to improve the quality of their core responsibilities in the workplace. They have the capacity and motivation to concentrate only on their task. Demerouti and Cropanzano (2010) concluded that involvement can improve performance as a result of a number of mechanisms.

\section{RESEARCH HYPOTHESES}

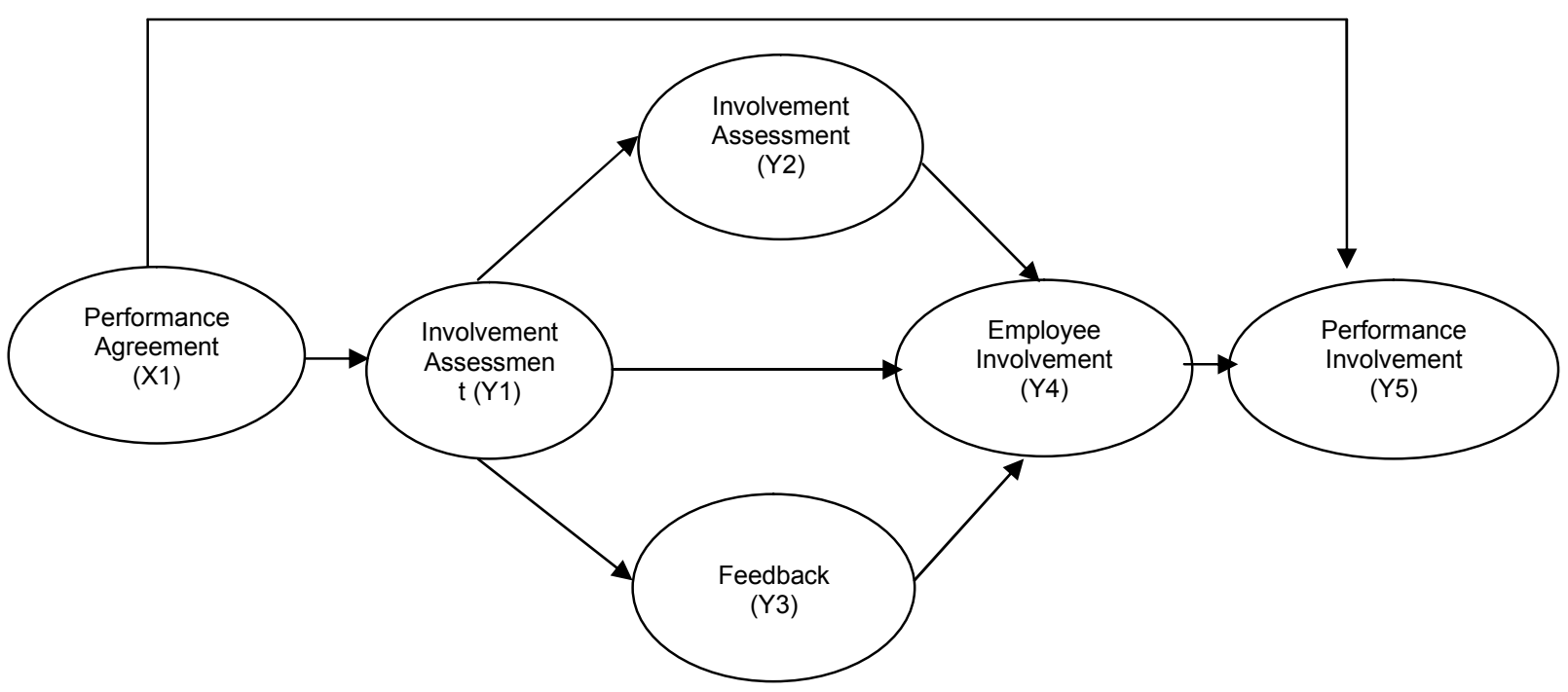

Figure 1 - Research Framework 
The research framework for this research can be seen from Figure 1. From the framework, several hypotheses can be formulated which are tested throughout this research.

H1: The increasing performance agreement will enhance the involvement facility. Employee involvement as described by Schaufeli et al. (2002, p. 74) is a spirit of dedication and positive absorption in fulfilling the part of the work related to our mind. Medlin and Green (2009) shows that there is a covenant relationship influence in the employee performance and involvement.

H2: Better performance agreement will be able to improve the employee involvement. Involvement facility is aimed to identify and provide employees with the resources they need so that employees have a sense of meaningfulness, secure and availability. Involvement facility includes work design, training, and social support as well as leadership (Gruman \& Saks, 2011). Furthermore, Poursafar, et al., (2014) showed that there is a relationship in between involvement facility and involvement assessment.

H3: The improvement of the involvement facility will increase the involvement assessment. Involvement facility and employee involvement have been expressed by Marisa Salanova et al, 2008, she said that involvement facility has a significant effect on the employee involvement.

H4: The better the involvement facilities, the better the employee involvement. Involvement feedback is a direct and clear input concerning the effectiveness of the work (Wexley and Yuki, 1992), it serves as an instruction to clarify and motivate an awarding. Involvement facility and feedback as declared by Marzano, et al, (2001) that providing feedback are one of the effective strategies. Atwater, et al, (2007), shows a significant difference between the involvement facility and the involvement feedback given by company managers.

H5: The improved involvement facilities will enhance the feedback. Involvement assessment is one of the ways that individuals do to increase their involvement (Saks, 2006). Rosemary Fisher, et al., 2014 said that involvement assessment affects the employee involvement.

H6: Better involvement assessment will improve employee involvement. The knowledge of the work achievement arises from the existence of performance feedback (Hackman, 1980). Atwater et al, (2007) and Aguinis et al., (2012) shows that there is a significant influence between involvement feedback to the employee involvement.

H7: The increasing involvement feedback will be able to intensify employee involvement. Employee performance is an individual or an organization's circumstances to be able to survive and thrive in this competition era that show the results in quality and quantity within a predetermined time. Swarnalatha and Prasanna (2012) shows that there is an influence in between the relationship of employee involvement and employee performance.

H8: Higher employee engagement will enhance employee performance. Employee performance is an individual or an organization's circumstances to be able to survive and thrive in this competition era that show the results in quality and quantity within a predetermined time. Performance shows mastery of skills (competencies) that includes: a specific expertise in the field of competence. An organization that is built by a system that consists of human resources, equipment and facilities, finance, and job mechanism will be an organization that has a good performance in case of the synergy between the components. The dynamic organization will always increase its productivity and maintain its physical resources, finance, marketing capabilities, as well as human resources. Those aspects are some of the important factors that are required for organizations to remain competitive (Fisher, et al., 2006). In addition to that, Rival, 2010) in Safaria \& Yunastiwi, 2013, explains that there is an influence in between the relationship of employee involvement and employee performance.

\section{METHODS OF RESEARCH}

The type of the research used is explanatory research in order to test the hypothesis between the variables of the study. It is intended to know the influence of the variables 
studied which are the independent variables and the dependent variables. In the other hand, the approach used in this study is the quantitative approach. The method is used to provide 150 questionnaires from the existing population, and then subsequently to be analyzed. The questionnaires were distributed to the employees of PT. Surya Pamenang, an enterprise based on Kediri, Jawa Timur Province, Indonesia.

\section{RESEARCH RESULTS}

Respondent Characteristics. From the questionnaires, it can be revealed that the characteristics of the respondents are as follows. The results of the research which are indicated by the male gender are $73 \%$, while the female respondents are only $27 \%$. This shows that the male employees are more dominating than the women employees. Moreover, according to age characterization, the results of the study indicated that the majority of the respondents is between $46-50$ years old by $29 \%$, between $51-55$ years old by $22 \%$, between $56-60$ years old $17 \%$, and then $10 \%$ between $36-40$ years old, $12 \%$ between $41-45$ years old while between 30 years old is only by $2 \%$ and $5 \%$ between $61-65$ years old. Based on the age structure, it shows that the respondent belongs to a productive employee group. Age affects job satisfaction, when the age of the employee is entering a stage of maturity, it will make them work properly.

The results of the study according to the respondents working period is very varied; between $0-10$ years $(26.67 \%)$, between $11-20$ years $(41.33 \%)$, between $21-30$ years $(32 \%)$, while the longest tenure, over 30 years, is $0 \%$. The respondents working period is mostly distributed in between 11 and 20 years at $41.33 \%$ and $32 \%$ between $21-30$ years. Based on years of service, it indicates that the respondents are satisfied and comfortable with the company. This company is dominated by senior employees who are productive and the remain of the employees consists of expertise workers and novice workers. By that, the company can operate productively.

Results of Analysis. There are two techniques of analysis employed in this study, namely, descriptive analysis and SEM analysis. Both analysis produce various findings.

Descriptive Analysis. This analysis is used to describe the variable of the performance agreement, facility, feedback, assessment, employee involvement and employee performance by distributing the items of each variable. The data which have been collected in the form of a question with determined multiple choice are brought to be tabulated into a table and discussed descriptively. The measurement of this description is by giving numbers, both in the number of respondents and the percentage as follows:

Based on the obtained data, the distributed questionnaires related to the performance agreement of the employees are measured by two indicators, such as goal-setting and psychological contract which are presented with the average value of the whole goal setting. Goal determination generates support for the employees, means that employees need the support of the leader in order to set the goals well. As a result, both company's goals and employee goals can be achieved. For that, the leader can create a conducive work situation so that the objectives can be achieved and the psychological contract enabled to produce the highest mean value on psychological safety. A psychological safety means employees require the safety in the first place even if the salary is not too big, enough for their individual interests and their families. Employees will try to do its best for the safety of the employees. Thus, the head of the company should try to be more understanding towards its employees in order to protect them and their families so that they could feel safe and comfortable in work.

Involvement facilities include some indicators like work design, social support, leadership, and training to produce the highest mean value of social support. It means that employees need support / assistance from other employees in order to perform their duties smoothly. Have an understanding among employees to perform the tasks and achieve company objectives and goals of the employees, so that it will get the support of the community. Furtherly, leaders should understand the employee, which can create a conducive work situation in order to get the support from the community. 
Involvement assessment covers several indicators such as performance evaluation, training and assessment to produce the highest mean on the indicator of employee training, means that the employee needs such assessment process in employee training in which the assessment process is a parameter of the level of understanding gained from the training. The leader of the company is expected to provide training and information that is easily understood by the employees as well as to give a good and competent tutor.

Involvement feedback consists of the quality effective, quantity, performance feedback, and information which aimed to produce the highest mean value in quantity effective, means that employees prefer to the quantity of the jobs. Job quantity is the required target of a company that needs to be met by the employees. This job quantity is the one which is purposely met by the employees in the first place. For that, leaders should understand the desire of the employees who prefer more on job quantity, then, leaders should monitor the work quality more. Due to the company's expectations in addition to the optimal quantity, good job quality is also required.

Employee involvement is measured by four indicators, namely productivity, employee satisfaction, profitability, and pride. By that, it is expected to produce the highest mean value on employee satisfaction, which means that employee prioritized job satisfaction from the company. The employees who are working earnestly will fulfill the company's goals and get the optimal profit. For an instance, employees will feel proud to have fulfilled the task with good company, and then job satisfaction is obtained.

Employee performance as measured by employees' attitude and employment is intended to produce the highest mean value in the attitude of the employees. This means that employees require reliability on their job, initiative, discipline, and have a deep understanding of the work. According to that, leaders should give an appreciation to the employees and always do a monitoring to create a conducive working situation. Giving appreciation to employees and maintaining conducive situation can be done by praise, rewards and provides motivation in order to improve the employees' ability continuously as well as increase the awareness of the importance of working together with other employees and leaders every morning or once a week.

SEM Analysis. SEM analysis is used to determine the amount of the independent variables on the dependent variable, as seen in Table 1.

Table 1. Influence path coefficients (standardized regression) between variables

\begin{tabular}{|ccc|ccccc|}
\hline & n/n & & Estimate & S.E. & C.R. & P & Information \\
\hline Y1 & $<---$ & $\mathrm{X}$ & 1.254 & 0.269 & 5.193 & ${ }^{* * *}$ & Significant \\
Y4 & $<---$ & $\mathrm{X}$ & 0.103 & 0.068 & 1.008 & .313 & Not Significant \\
Y2 & $<---$ & Y1 & 0.517 & 0.080 & 4.778 & ${ }^{* * *}$ & Significant \\
Y4 & $<---$ & Y1 & 0.091 & 0.089 & 0.610 & .542 & Not Significant \\
Y3 & $<---$ & Y1 & 0.351 & 0.103 & 3.744 & $* * *$ & Significant \\
Y4 & $<---$ & Y2 & 0.362 & 0.100 & 2.945 & .003 & Significant \\
Y4 & $<---$ & Y3 & 0.222 & 0.050 & 2.426 & .015 & Significant \\
Y5 & $<---$ & Y4 & 0.992 & 0.232 & 6.896 & $* * *$ & Significant \\
\hline
\end{tabular}

Performance agreement variable $(X)$ towards involvement facility $\left(Y_{1}\right)$. With a standardized coefficient of 1,254 and $C R$ which is identical to the $t$ value, it shows that the figure is more than 1,960 with the probability of 0,000 . Say that the performance agreement variable $(X)$ has a positive and significant influence towards the involvement facility $\left(Y_{1}\right)$.

Performance agreement variable $(X)$ towards employee involvement $\left(Y_{4}\right)$. With a standardized coefficient of 0,103 and $C R$ which identical to $t$ value and shows less than 1,960 with the probability of 0,313 . So, it can be said that the performance agreement variable $(X)$ does not influence the employee involvement significantly and positively $\left(\mathrm{Y}_{4}\right)$.

Involvement facility variable $\left(Y_{1}\right)$ towards involvement assessment $\left(Y_{2}\right)$. With a standardized coefficient of 0,517 and $C R$ which identical to $t$ value. The value shows more than 1,960 with the probability of 0,000 . It can be concluded that the involvement facility variable $\left(Y_{1}\right)$ has a positive and significant effect towards involvement assessment $\left(Y_{2}\right)$ 
Involvement facility variable $\left(Y_{1}\right)$ towards employee involvement $\left(Y_{4}\right)$. With a standardized coefficient of 0,091 and $C R$ which identical to $t$ value. It shows that the value is less than 1,960 with the probability of 0,542 where it means that the involvement facility variable $\left(Y_{1}\right)$ does not affect the employee involvement positively and significantly $\left(Y_{4}\right)$

Involvement facility variable $\left(Y_{1}\right)$ towards involvement feedback $\left(Y_{3}\right)$. With a standardized coefficient of 0,351 and $C R$ which identical to $t$ value of more than 1,960 with the probability of 0,000 . It can be concluded that the involvement facility variable $\left(Y_{1}\right)$ influenced the involvement feedback positively and significantly $\left(\mathrm{Y}_{3}\right)$

Involvement assessment variable $\left(Y_{2}\right)$ towards employee involvement $\left(Y_{4}\right)$. With standardized coefficient of 0,362 and $C R$ which identical to $t$ value of more than 1,960 with the probability of 0,003 , it can be said that the involvement assessment variable $\left(Y_{2}\right)$ gives a positive and significant effect towards the employee involvement $\left(\mathrm{Y}_{4}\right)$

The involvement feedback variable $\left(Y_{3}\right)$ towards employee involvement $\left(Y_{4}\right)$. With standardized coefficient of 0,222 and $C R$ which identical to $t$ value of more than 1,960 with the probability of 0,015 , it means that the involvement feedback $\left(\mathrm{Y}_{3}\right)$ positively and significantly affects employee involvement $\left(\mathrm{Y}_{4}\right)$

Employee involvement variable $\left(Y_{4}\right)$ towards employee performance $\left(Y_{5}\right)$. With a standardized coefficient of 0,992 and $C R$ which identical to $t$ value. The value of $t$ is more than 1,960 with the probability of 0,000 so that it can be said that the employee involvement variable $\left(\mathrm{Y}_{4}\right)$ has a positive and significant influence towards the employee performance $\left(\mathrm{Y}_{5}\right)$.

Research Implications. The final result of each study is expected to give the implications for the development of science. The implications of these results are grouped into theoretical implications and practical implications.

Theoretical Implications. The theoretical implications, in general, are referring to the concept of research which contains the relationship of the concept. The followings are the theoretical implications of this research:

1. The existence of performance agreement which clearly supports involvement facility, it has the implications for the employee to set goals and to psychologically get a sense of meaningfulness, availability, and safety. The companies which can provide a sense of security and comfortable work situation will obtain the achievement of the company.

2. Performance agreement which does not support the employee involvement has the implications for employees such as if in the event of a promotion is not accompanied by a new performance agreement, it will reduce the sense of meaningfulness and availability and degrade the performance of the employees. The company which has the implications could select and assess which one is the loyal and dedicated employees.

3. Involvement facility increases the involvement assessment, it is on the job of the employee (design the employment, social support, confidence in leading and get training from the company). Those have raised its involvement assessment in the performance evaluation which is conducted by the supervisor. Training and implementation in the assessment itself have such implications for the employees, it can boost their confidence and they can be meaningful in the company. Meanwhile, the company can improve employee performance and the employee will feel meaningful and understand the company's goals.

4. The involvement facility does not support the employee involvement because the leader of the company is less identifying the skills and the identity of the employee's duty and less appreciate the feedback / reports from subordinates to be adapted to the role of employees according to their skills. This has implications for the maximum employee's performance because the leader was less precise in selecting the employees in accordance with their skills and job descriptions. Besides that, companies may suffer losses, both in terms of time, work quality and quantity that can reduce / interfere the production process.

5. The involvement facility supports the involvement feedback, the implication of this is that employees can feel safe and comfortable in their workplace. Here, the 
companies can create a conducive work situation so that the employee performance can be improved.

6. Employee involvement assessment strengthens the employee involvement related to the performance evaluation, assessment, and training. Employees will feel calm, peaceful and valued in their work so that the pride and job satisfaction can be felt. The company can create a work situation that is safe and comfortable for the employees so as to increase the company productivity and profitability.

7. Involvement feedback supports the employee involvement. It has the implications for the employees such as calm, peaceful and valued feeling in their work so that the pride and job satisfaction can be felt. Companies also can create a safe and comfortable work situation so as to increase the company productivity and profitability

8. Employee involvement strengthens the employee performance to achieve a better quantity, quality, and production in a predetermined time. Employees will feel pride and satisfaction, they have been understood the interest, goals and everything related to the duties of the employees. Furthermore, companies will get optimal productivity and profitability.

Practical Implications. Practical implications are essentially a result of the benefits of the research that can be applied in the field. The practical implications of this research are:

1. Employees can motivate other employees to relate to the psychological conditions of the employees (meaningfulness, availability, and safety) according to the opinion of Kahn (1990).

2. Company leader can improve employee performance by creating a safe and peaceful conditions for the employees so that the productivity can be increased.

Research Limitations. The limitations of this research are twofold. First, in this study, the data are cross-section, so that the research results do not reveal the phenomenon of the research from time to time as the business expands. Second, this study also cannot be generalized to other companies.

\section{CONCLUSIONS}

Based on the analysis and discussion, this study can be summarized as follows:

The existence of performance agreement which clearly supports the involvement facility means that this company's performance agreement that consists of goals setting and psychological contracts support the involvement facility. Employees are free to design the work, to get social support, to gain confidence in the lead earnestly, and to receive training from the company, those activities are aimed to improve the employee performance

In this research, performance agreement is not supported the employee involvement, this means that in this company there has been a shift or development in the assignments or tasks due to reaching a higher career. It is said that it is not supporting because it is not accompanied by a new performance agreement; employees are satisfied with the additional working facilities and additional salary bonus without a new performance agreement.

Involvement facility improves the involvement assessment, where employees of this company do the job of designing the job, social support, confidence in leading and receive training from the company. This has raised its involvement assessment in the performance evaluation conducted by the supervisor, also in the training assessment and the implementation itself,

The involvement facility does not support the employee involvement due to the lack of the leader's identification skills to identify the employee's duties and feedback / reports. The feedback or reports are used to be adapted to the role of the employees in accordance to their skills, and besides that, the company has put a priority on employee involvement in the facility involvement.

Involvement facility supports the involvement feedback, in which the effectiveness of the work and the information distribution from the subordinates to the leader, vice versa, are already well established. The leader has been coordinating the work and providing guidance 
in making design / organize the work itself so that employees are working in accordance with the company objectives.

The assessment of employee involvement strengthens the employee involvement related to the performance evaluation, assessment, and training. The achievement of the objectives has increased the productivity and profitability of the company so that employees feel satisfied and proud to work for the company.

Involvement feedback supports the employee involvement where it includes effectiveness and information distribution. The performance feedback has been supporting the productivity and profitability of the companies, it makes the employees feel proud and satisfied with the company.

Employee involvement strengthens employee performance to achieve the company quantity, quality, and production in a predetermined time. Employees here will feel proud and satisfied with their work, they have understood the purpose, targets, and everything that is related to the employee's duties.

Meanwhile, based on the discussion and result of the research, it can be suggested that:

For the company. The leaders of the companies need to create a psychological condition that can increase the performance agreement, especially about the seriousness of performing the work. To have a better working willingness and desire for the employee who is obedient to the values and objectives of the company. So that, the career as the employee is proudly presented as a profession and not as a side job. This can be done by holding a weekly briefing or evaluation to evaluate the work that has been done and to plan the activities that are going to be implemented.

For the researcher. For the researchers in the field of human resources, it is expected to develop this research by adding several constructions (variables) or objects of the research where it will differentiate the characteristics of individuals, organizations, employment, culture and effective leadership, so that it will develop and add the knowledge in the management field.

\section{REFERENCES}

1. Atwater, L.E., Brett, J.F., \& Cherise-Charles, A. (2007). Multisource feedback: Lessons Learned And implications for practice. Human Resource Management, 46, 285-307.

2. Buchner, T.W. (2007). Performance management theory: A look from the performer's perspective with implications for HRD. Human Resource Development International, 10, 59-73.

3. Demerouti, E., \& Cropanzano, R. (2010). From thought to action: Employee Work engagement and job performance. In A. B. Bakker \& M.P. Leiter (Eds.), Work Engagement: A handbook of essential theory and research (pp.147-163). Hove, East Sussex: Psychology Press.

4. Giles, W.F., \& Mossholder, K.W. (1990). Employee reactions to contextual and session components of performance appraisal. Journal of Applied Psychology, 75, 371-377.

5. Gruman, J.A. \& Saks, A.M. (2011). Performance management and employee engagement. Human Resource Management Review 21, 123-136.

6. Hackman, J.R., \& Oldham, G.R. (1980). Work redesign. Reading, MA: Addison-Wesley.

7. Kahn, W.A. (1990). Psychological conditions of personal engagement and disengagement at work. Academy of Management Journal, 33, 692-724.

8. Leiter, M. P., \& Bakker, A. B. (2010). Work engagement: Introduction. In A. B. Bakker \& M. P. Leiter (Eds.), Work engagement: A handbook of essential theory and research (pp. 1-9). Hove, East Sussex: Psychology Press.

9. London, M. (1995). Giving feedback: Source-centered antecedents and consequences of constructive and destructive feedback. Human Resource Management Review, 5, 159-188.

10. Macey, W. H., \& Schneider, B. (2008). The meaning of employee engagement. Industrial and Organizational Psychology, 1, 3-30. 
11. Macey, W. H., Schneider, B., Barbera, K. M., \& Young, S. A. (2009). Employee engagement: Tools for analysis, practice, and competitive advantage. Malden, WA: Wiley- Blackwell.

12. Medlin, B. and Green Jr., K.W. (2009) Enhancing performance through goal setting, engagement, and optimism. Industrial Management \& Data Systems, Vol. 109, No. 7, pp.943-956.

13. Murphy, K. R., \& DeNisi, A. (2008). A model of the appraisal process. In A. Varma, P. S. Budhwar, \& A. DeNisi (Eds.), Performance management systems: A global Perspective (pp. 131-146). New York: Routledge.

14. Poursafar, A., Rajaeepour, S., Seyadat, S.A., and Oreizi, H.R. (2014) The Relationship Between Develop-mental Performance Appraisal, Organizational Support, Organizational Commitmen and task performance: Testing a Mediation Model. International Journal of Human Resource Studies. DOI: http://dx.doi.org/10.5296/ijhrs.v4i2.5765.

15. Pulakos, E. D., Mueller-Hanson, R. A., \& O'Leary, R. S. (2008). Performance management in the United States. In A. Varma, P. S. Budhwar, \& A. DeNisi (Eds.), Performance management systems: A global perspective (pp. 97-114). New York: Routledge.

16. Rousseau, D. M. (1990). New hire perceptions of their own and their employer's obligations: A study of psychological contracts. Journal of Organizational Behavior, 11, 389-400.

17. Safaria, S. and Yunastiwi, A.S. (2013). Pengaruh Keterlibatan Kerja terhadap Kinerja Pegawai pada PT. Seascape Surveys Indonesia. E-Journal Manajemen dan Bisnis, Vol. 1, No. 3.

18. Saks, A. M. (2006). Antecedents and consequences of employee engagement. Journal of Managerial Psychology, 21, 600-619.

19. Saks, A. M., \& Gruman, J. A. (2010). Socialization resources, PsyCap and employee engagement. Unpublished raw data.

20. Schaufeli, W., \& Salanova, M. (2007). Work engagement: An emerging psychological concept and its implications for organizations. In S. W. Gilliland, D. D. Steiner, \& D.P. Skarlicki (Eds.), Managing social and ethical issues in organizations (pp.135-177). Greenwich, CT: Information Age Publishing.

21. Schaufeli, W. B., \& Salanova, M. (2008). Enhancing work engagement through the management of human resources. In K. Näswall, J. Hellgren, \& M. Sverke (Eds.)The individual in the changing working life (pp. 380-402). New York: Cambridge University Press.

22. Schaufeli, W. B., Salanova, M., Gonzalez-Roma, V., \& Bakker, A. B. (2002). The measurement of engagement and burnout: A two sample confirmatory factor analytic approach. Journal of Happiness Studies, 3, 71-92.

23. Swarnalatha, C. and Prasanna, T.S. (2012). Increasing Organizational Commitment of Employees: By Correlation of Goal Setting, Employee Engagement and Optimism in the Organization. International Journal of Advances in Management and Economics, Vol. 1, Issue 6, pp.40-44.

24. Swarnalatha, C. and Prasanna, T.S. (2013). Employee Engagement : A Theoritical Approach. International Journal of Human Resource Management and Research, Vol. 3, Issue 1.

25. Turnley, W.H., Bolino, M.C., Lester, S.W., \& Bloodgood, J. M. (2003). The impact of psychological contract fulfillment on the performance of in-role and organizational citizenship behaviors. Journal of Management, 29, 187-206.

26. Wrzesniewski, A., \& Dutton, J.E. (2001). Crafting a job: Revisioning employees as active crafters of their work. Academy of Management Review, 26, 179-201. 